\title{
A Comparative Study of the Extent and Scope of Absolute Guardianship of the Islamic Jurist, (Vilayat-e Faqih) from the Perspective of Shiite Jurists; and the Rashidun Caliphate in the View of Sunni Scholars
}

\author{
Seyed Mohammad Reza Ayati ${ }^{1} \&$ Mahdi Moghaddasi ${ }^{1}$ \\ ${ }^{1}$ Jurisprudence and principles of Islamic Law, Science and Research Branch, Islamic Azad University, Tehran, \\ Iran \\ Correspondence: Mahdi Moghaddasi, Jurisprudence and Principles of Islamic Law, Science and Research \\ Branch, Islamic Azad University, Tehran, Iran. E-mail: moghaddasi.mahdi7718@gmail.com
}

Received: May 28, 2016 Accepted: June 17, 2016 Online Published: June 29, 2016

doi:10.5539/jpl.v9n5p247 URL: http://dx.doi.org/10.5539/jpl.v9n5p247

\begin{abstract}
"Vilayat" literally means manager and governor as well as master. Absolute means complete power and authority. From the perspective of the Shia, this authority is in fact dedicated to God, and God has been assigned it to prophets and their successors, and in the time of occultation of Imam Mahdi (AS) to Wali faqih (the guardian jurist leading Islamic community). Just jurist has all the powers and authorities (including political) assigned to the Prophet (PBUH \& HP) and the Imams (AS) for governance. In contrast, the Sunnis believe that religious texts are silent about the matter of government after the prophet (PBUH\&HP), and they did not speak clearly about the system of government and the conditions of Islamic leader and the ways of selecting him. Hence, they followed a choice theory in determining the political system of Muslims after the death of the holy Prophet (PBUH\&HP), and accepted caliphate system for ruling the Muslim community. Thus, according to the achievements of this research gathered in a descriptive-analytic method, the Shiite believes that the immaculate Imams (AS) appoints leaders of Muslims community, while Sunnis believe in choosing leader by people.
\end{abstract}

Keywords: Shia, Sunni, Vilayat (guardianship), Absolute Guardianship of the Islamic Jurist

\section{Introduction}

In the monotheistic worldview of Islam, the absolute property right of all creatures and phenomena in the world belong only to God. Human beings and all other creatures are under the sovereignty of God and government is God's exclusive right. Man moves towards perfection through obeying the divine commands. In such society that is governed by the laws of God, human talents will flourish in the light of recognizing the right. In such a society, ownership and domination of a minor group over resources and public wealth and facilities of society, and any oppression and discrimination will be eliminated and justice will established.

Therefore, in the view of Islam, any division of society into groups such as governor and subordinate, master and servant, or granting the right to rule and legislation to an individual or a class are oppression. For Islam, only those groups of people who are aware of the divine law, believe them, and are best in fear (of God) and justice are competent to execute the divine laws on behalf of God. Prophets and their successors, namely the Imams (AS) are at the head of this group, and in their absence, the righteous and devout people continue their way. This research aims to examine the scope and limit of the jurist guardianship, with respect to the questions as to whether or not the authority of jurist is excluded to the guardian-less activities (Omur-al-Hesbia in Islamic society), or if he have power to issue a Jihad order in the time of occultation.

\section{Semantics for Absoluteness of Vilayat (Guardianship)}

Absoluteness of vilayat is used in two senses: first, in the meaning that the jurist has all the powers of the immaculate Imams (AS) and that not only he has an absolute authority in political and governmental affairs, but also enjoys other powers of the immaculate Imams (AS). In other words, in the legislative guardianship (vilayat) there is no distinction between the jurist and the Infallible Imam (AS). The second meaning is that there is no difference between a qualified jurist and the infallible imams (AS) in enjoying government powers, and the jurist 
has all powers the holy prophet (PBUH\&HP) and the infallible imams (AS) had to run the country, unless those powers excluded to the infallible Imam (AS) on the basis of reasons, such as initial jihad. The late Imam Khomeini has used the Vilayat-e Faqih in the same means. What was called "Vilayat-e Faqih "by most jurists, was called "public governance", "the general public governance" or "the general divine rule" by Imam Khomeini. For him, this is the realm of the infallibles (AS), and as it stated in his religious (Fiqh and Usul ) books, It has higher than governance of the just jurists. In addition, he called "absolute guardianship" what the other famous jurists have named "Public guardianship". (Kadivar, 121-3)

\section{Powers of Wali e Faqih (Islamic Jurist)}

The authority mentioned for the Wali e Faqih are as follow:

1) Fatwa authority; i.e. jurists have certain right to express their view on the divine commandments, and jurist's vilayat on this respect is undoubted according to the approach of the famous jurists. In addition, fatwas issued by the jurists are binding for their followers, a matter confirmed by all predominant jurists.

2) Judicial powers; i.e. dispute settlement and issuing judgment are of general and noble goals of prophets' invitation and the characteristics of the Imams (AS), and in the time of occultation of the infallible Imam (AS), this authority and responsibility has been assigned to just jurist, that is accepted by all the jurists including those who accept "the public representation" as well as opponents.(Khansari Najafi, 1/325; Najafi, 21/397) 3. Obedience vilayat; i.e. in all cases that within the framework of general divine commandments one may express view, a jurist has such right. 4. Guardianship for administration of justice; i.e. the administration of justice and validating the divine law requires enforcement of criminal laws and punishment of offenders. Thus, the authority responsible for enforcement of the Divine command has power for enforcement of commands and regulations. 5. Vilayat for possession in matters related to the life and property of the people. According to most jurists, this type of vilayat is excluded to the infallible Imam (AS) and cannot be accepted for jurist. 6. Vilayat in public affairs and political leadership; in the sense of vilayat in Islamic administration of the community, which is the requirement of caliphs and leaders of the Islamic community, and includes all the powers of ruler of the community. This is the idea of Imam Khomeini, Ayatollah Naeini, and Ayatollah Golpayegani and many contemporary jurists. 7. Vilayat in the guardian-less activities; an authority accepted by all jurists. 8. Vilayat in primary jihad; most jurists believe that jurist does not have vilayat and power in primary jihad and even if this issue is not consensus, there is no different views about it even in contemporary books on guardianship of the Islamic Jurist.

Given the mentioned authority for Wali e Faqih, it can be said that he has vilayat over two types of affairs; namely affairs that should be done and affairs that need Imam's direct involvement.

\section{Vilayat in Limited to Existence of Interest in Possession}

There are three theories about the vilayat of the holy Prophet (pbuh\& hp) and the Infallible Imams (AS): 1. they do not have guardianship over the property and life (of Muslims), 2. Their guardianship is absolute, 3- their vilayat depends on existence of interest, i.e. only those possessions that may cause benefit of the people would be valid.

Accordingly, the holy Prophet (PBUH\&HP) and infallible Imam (AS) cannot order a woman to marry a non-peer man. In addition, he cannot seize another person's property or sell it due to his needs. therefore, the Prophet (PBUH\&HP) and the Infallible Imams (as) are as guardian for children and then must consider the interests of children, and the holy God has given them guardianship simply because they recognize people's interests over harm better than them, and the objective is leading people towards what is good for them.

Indeed, there is no ground for discussion about the third theory, which states Vilayat in not Limited to existence of interest in possession, because the Prophet (PBUH\& HP) and the Infallible Imams (AS) do not have passion, but are the kindest humans on earth. Many hadiths and sayings are our reason for this. ${ }^{1}$

In a long hadith, Imam Reza (AS) introduced the appointed Imams (AS) as kind fathers and compassionate brothers and refuge of servants in incidents. The necessity of permission of the holy prophet (PBUH\&HP) and the Infallible Imams (AS) for (jurist's) possession

Another argument about the vilayat of the Prophet and the Imams (AS) on the property and life is that whether transactions, worships, or every act of people should be done with the permission of the infallibles (AS)? Other question is that whether transactions and worships done without such permission are void and the doer is considered sinful for the, or is permission unnecessary?

\footnotetext{
${ }^{1}$ See Saduq, Amali al-Saduq, P. 604; Koleyni, Vol.1,P. 222.
} 
For example, whether someone who wants pray or sell his/her house should get permission of the Imam is (AS)? However, the necessity of permission in all acts needs accepting the absolute guardianship of the infallibles. Sheikh Ansari stated that the necessity of permission of the Prophet and the Infallible Imams (AS) for possession is contrary to principle. He added: some acts and possessions need Imam's permission because they are duty of the leader. For example, according to texts, acts such as execution of sanctions and seizure of property of guilty persons require permission of the Prophet (PBUH\&HP) and Imam (AS). (Ansari, 153)

Our reason for this claim is a hadith of Imam Reza (AS), narrated by Fazl ibn Shazan in which Imam (AS) has emphasized the importance and necessity of existence of leader for any nation to enforce religious, governmental and defense affairs and establish order and security in society and so on. (Saduq, Oyun Akhbar Al-Ridha, 2/204)

However, one cannot find a population and nation that continues its social life without having a leader and guardian for doing indispensible worldly and otherworldly affairs.

Then, according to the wisdom of wise and honest God, it is not permissible to leave people without leader and administrator, while people cannot continue its life without leader and that determining a leader is necessary. Islamic leader fends off enemies, divides public property among people, leads Friday Prayers and social worships, and prevents oppressors of oppressing weak people. The above-mentioned hadiths and human wisdom emphasize that humankind needs leader and therefore any nation continuing its social life needs a leader. The necessity of a leader comes from the fact that some needed social actions such as dividing public property, holding Friday Prayers and congregational Prayer, and getting the right of the oppressed from the oppressor.

According to the above mentioned, it is necessary to mention two matters: first, that the actions and possessions are divided into three categories; possessions that are of duties and responsibilities of the leader and not people, and possessions that are of duties of the people, without need to the permission of the leader; such as worships and transactions. The third category includes possessions that are of duties of the people but are subject to the permission of the head (leader), such as retaliation or almsgiving of property whose owner is unknown. (Iravani, 155)

In fact, wise people of any race and religion anywhere in the world refer to a chief in matters that are of his/her responsibility, and do them without his/her permission in other matters that are not the responsibility of the chief.

Then behavior of the wise is the best reason for the necessity of permission from the holy Prophet and the Imams (AS) in public affairs, and they deem necessary permission of the leader on public affairs, while see permission invalid in possessions that are of individual affairs and needs no public permission.

According to the subjects mentioned, we are now going to discuss about the guardian-less activities (Omur al-Hesbia in Islamic society) and determine the scope of authority of Islamic leader. The question is that whether these authority is limited to a few things (most of it Hesba)? On the other hand, is such authority not excluded to hesba and affairs of incapable persons?

\section{The Guardian-Less Activities}

"Hesbia" literally means reward, and in legal terms, is said to guardian-less affairs that have no particular guardian (person or entity). On the other hand, we know that God is not happy with pending affairs, such as guardianship of unattended children and maintaining their property, burying Muslims who do not have relatives. (Tabrizi, 10, 12). Vilayat in the guardian-less activities means that the jurist has priority over other people in doing these affairs.

In other words, the right to do these things is excluded to the jurist until he is present, and with his absence or denial of possession, faithful people are responsible.( Salehi Mazandarani, 57) scope of the guardian-less activities is any matter related to life and religion of people, because worldly and otherworldly affairs of some people or groups and the order of religious and worldly affairs of Muslim community depends on It. Doing the guardian-less activities is a religious order and most of jurists accept it. In addition, it is necessary for negating damages and hardship and some other reasons.

However, jurists have the duty of doing actions that have necessity or religious permission, while religious resources have not entrusted them to a certain or uncertain individual or group.

\section{Reasons for Authority of the Jurist in the Guardian-Less Activity}

The two reasons are as follow: 1. Consensus. 2. The holy God is kind and wise so he has appointed guardian for any affair, and assuming that a certain or uncertain person or group have not been determined , then the jurist is implicitly appointed for such affairs, because Islamic resources has used suitable attributes exclusively about the jurists. This is enough to indicate that the jurist is appointed to these matters. Another reason is that it all 
requirements (including being Muslim, just and reliable) required to undertake any necessary and guardian-less affairs involves the jurist.

Accepting guardianship of anyone means accepting the guardianship of jurist, but establishment of guardianship of the jurist needs people. Such jurist is the caliph and leader of Muslims and the result is his guardianship is established and other jurists do not any guardianship right. (Naraqi, 61) the late Naini says: for public reasons, guardianship of the jurist includes the guardian-less activities. Perhaps this is because the guardianship of such jurist is established, or due to lack of chaos. (Najafi, 297/20)

Therefore, the result of the mentioned discussions is that the principle of velayat-e faqih is of certainties in shiite jurisprudence, and all jurists are unanimous on it. Therefore, anyone who claims an opposite view is alien to the Shiite jurisprudence and views of the Shia jurists.

However, dispute is in the authority scope of the Wali e Faqih. There are two main theories on this subject; a theory accepts the limited guardianship of the Islamic jurist (i.e. right of possession in social affairs), and another insists on the absolute guardianship of the Islamic jurist. Both of the (minimum and maximum) theories will be examined below.

\section{Minimal Theory (Limited Guardianship of the Islamic Jurist)}

Some of the past jurists believe that jurist does not have absolute guardianship, and their guardianship right is only in the guardian-less activities. The non-litigious matters (or guardian- less activities (al-omour al-hesbiah) include guardian-less matters such as judicial matters, guardianship of minors and insane, religious endowments, and the property for which no specific person is responsible. Of the most important supporters of this theory, we can refer to Sheikh Ansari, Allama Naini and Ayatollah Khoei. Allama Naini says: "in matters that we know are suitable at any time in religion for which no specific person is responsible, the only responsible authority is jurist." (Khansar Najafi, 329/2)

In this respect, Ayatollah Khoei says: "guardianship at the time of occultation of the Imam (AS) is not proven for jurist by any evidence, but guardianship is dedicated to the Prophet (PBUH\&HP) and the Imams (AS) and two matters are used of the hadiths: " legitimation of jurist's judgment" and "validity of his fatwa", but he does not have permission to possess in matters of guardianship, except in the guardian-less activities. "(Khoei, 258) they argue that the holy legislator (God) has no command on the matter of government during the time of occultation of Imam (AS), and has not obliged anyone to establish government, so the people are not required to obey someone except in the guardian-less activities.

This claim needs at least two requirements: first, in terms of the jurisprudence, no one does not have guardianship right over community and people are free to form any kind of government they want, that is sovereignty right belongs to the people, and can choose everyone they want as governor.

Secondly, the governor is not guardian of people but is their representative, because the people have selected him to such position. Guardianship in the non-litigious matters is the minimum extent that this category of shia jurists accept for the Wali e Faqih. There is no consensus in respect of absoluteness of guardianship but most of jurists accept the absolute guardianship of the jurists. According to the limited guardianship of the jurist, not only formation of government in the time of occultation is not obligatory, but also jurists have no right to form the government.

\section{Maximum Theory (The Absolute Guardianship of the Islamic Jurist)}

Most Shia jurists believe that the Wali e Faqih has the same guardianship that the Prophet (PBUH\&HP) and the Infallible Imams (AS) had in social and political affairs, unless the cases that certain reasons exclude them. Scholars such as Mohaqeq Karaki, Naraghi, Najafi, Seyyed Bahrel olum, and Imam Khomeini were supporting the Absolute Guardianship of the Islamic Jurist and even claim being of consensus on it among shia scholars. Even some scholars go ahead and consider it of certainties and necessities.

From the viewpoint of these scholars, the Guardianship of the Islamic Jurist during the occultation of Imam (AS) is continuation of guardianship of the holy prophet (PBUH\&HP) and the infallible Imams (AS). This belief requires being of a qualified jurist at the head of the Islamic community. (Hadavi Tehrani, 63)

On this basis, the formation of state is of guardianship's affairs. Wali e Faqih has a divine right and duty to involve in all matters including political, economic, social and so on. This is because the holy legislator does not ignore the matter of governance during occultation of Imam (AS).

From this perspective, legitimacy of the government is divine, although its popularity depends on the will of the people, and its objective realization is based on public will and participation. The just Islamic governor is 
guardian of the people and not representative, then the people must obey his commands in all respects. In this regard, Ayatollah Najafi says, by not rejecting full guardianship for the jurist, many affairs related to the shiites will remain undone. He adds: after the Imams (AS) strictly forbade (the Shiites) from referring to the unjust judges and scholars and rulers, the principle of necessity requires that the jurist can implement decrees for getting the public rights. (Najafi, 297/20). In other part, he says: "jurists always refer to the guardianship of the Islamic jurist in cases for which there is absoluteness reason, and this absoluteness is approved by the religious laws as well as severe necessity". (Ibid, 422/15)

Imam Khomeini said: "the guardian-less activities include affairs that God is not content to leave them undone. If such activities have a special or general guardian so there is no discussion but if they were of affairs subject to discretion of Imam (AS), the jurist would be responsible for them in his absence, and at the time of uncertainty among the just or reliable jurist, our preference is just jurist... and in the absence of a jurist, faithful persons would be responsible for the guardian-less activities. However, there is no religious reason (or text) for this and as a result such guardian (faithful) does not right to appoint or dismiss, but the jurist has right to appoint and dismiss due to being appointed by the religion...(Imam Khomeini, 665/2)

Ayatollah Golpayegani says: the guardian-less activities are matters that because of interest in their realization, the holy God does not want them to be leaved, though a certain person is not obliged to do them. The guardian-less activities are divided into two categories: first, the affairs related to leadership of community for which the jurist has guardianship (based on hadiths), second, the affairs that do not relate to the society order and at the same time the holy legislator is not satisfied to leave them. Also these affairs should be enforced by the jurist... for example, the burial affairs of the guardian-less dead, or selling the property of minor due to maintain his/her life, which does not relate to the society order...(Gulpaigani, 813)

After quoting the sayings of famous scholars, adding some points on the guardian-less activities is essential. First, there is relationship between the guardian-less activities and the public affairs, and the two have common as well as exclusive cases. For example, pricing of goods belongs to public affairs, but appointing the governor for a city is both a case of the guardian-less activities and the public affairs. As a result, guardianship over the public affairs does not require having guardianship over the guardian-less activities.

Second, what is derived from the words of jurists is that in all the guardian-less activities the responsibility is on the jurists, but this is not case in all the guardian-less activities and any individual whose act is near to the interest of the subject, may have guardianship.

For example, maintaining the minor's property is of good things, and if a non-jurist just faithful is more successful in maintaining the minor's property through transactions in favor of Minor, then he/she is preferable to the jurist and has guardianship without need to his permission. However, in those activities such as political sovereignty, and executing religious orders in which knowing the religious commands is necessary, the guardianship is exclusively assigned to the jurist and not just believer. Third, according to the scholars' words, without a religious or intellectual reason, neighed a jurist nor other believers don't have any guardianship, but the question is that how can be the holy legislator not satisfied with an omission while at the same time leave it without an appointed guardian and responsible.

According to the two theories presented, we believe that guardianship of the jurist cannot be excluded to the guardian-less activities because affairs of the Muslim community will be impaired, and due to the interest of society he should have the authority beyond the guardian-less activities.

\section{Primary Jihad}

One of the most important issues that seem necessary in the field of guardianship of the jurist is primary jihad and the question that whether the ruling scope of the jurist includes primary jihad. Jihad is of essential duties in Islam and there are many verses and hadiths about it. scholars have divided jihad to the primary and defensive. Primary Jihad is fighting the unbelievers and inviting them to Islam. In this kind of jihad that Muslims were not its initiator, the aim is eliminating the domination of infidels and providing the possibility of spread of the divine religion (Islam).

Defensive jihad is fighting the invaders to life, property or the land of the Muslims. There is no doubt that defensive jihad is subject to the permission of the infallible Imam (AS); but as scholars say, the duty of primary Jihad is subject to the permission of the infallible Imam (AS) and the person who is appointed by him. Thus, the primary jihad is not legitimate by the permission of the qualified jurist during the occultation of Imam (AS) and thus he/she does not have such authority. In this respect, the supreme leader Ayatollah Khamenei says: primary Jihad does not excluded to the era of the holy prophet (PBUH\&HP) and the infallible Imams (AS), and the 
qualified jurist who responsible for guardianship of the Muslims can issue order of primary jihad in the case of interest.

Jihad with property and soul is a duty by God for his servants under the leadership of the just Imam (AS), and an individual who don't have the power of jihad with Imam (AS) by his/her property and soul, must give his/her property to someone for jihad on his/her behalf. From the opinions of the ancient scholars about the necessity of primary jihad under the condition of presence of Imam (AS) or his deputy, we can understand the following points: First, the difference between the ancients about the condition of the Imam or his deputy in Primitive Jihad there. Second, there jurists conditioning early in the Imam (AS) is the same traditions in the authentic ahadith books and it is for two reasons: First, there is no difference between the ancient jurists about the condition of the existence of Imam (AS) or his deputy for incumbency of primary Jihad. Second, documents of the ancient scholars in this respect are those hadiths noted in the authentic ahadith books. Imam (AS) appoints some for jihad and some other for any matters. Here the difference point is that whether or not the latter person can invite people for jihad. Some of the past scholars such as Sheykh Tousi (Mabsut), Ibn Hamza (Vasilah), Ibn Idris (Sarair), and Muhaqqeq (Al-Mukhtasar AL-Nafi) have believed that jihad is obligatory only at the invitation of the deputy appointed for jihad affairs, while some other such as Ibn Albaraj (Muhazab), Ibn Zuhra (Qaniyah), Allameh (Al-Risala Al-fakhriyah) and Shahid Awal (Al-Durus Al-shoruiyah, Luma Al- Demishqiya) believed that an appointment for doing any matters is sufficient for jihad invitation.

On can find the result of what was mentioned in the words of Imam Khomeini in this regard: the jurist has all (governmental) authority of Imam (AS), unless evidence presented in contrary (Khomeini, 2/664). However, it can be said that according to hadiths in the Shiite thought system, one cannot say that Jihad is not authority of the jurist or governor.

\section{Jihad in Sunni School}

After discussing the realm of orders of Islamic ruler in the framework of jihad and especially primary jihad from the Shiite perspective, now we are to examine this subject in Sunni thought. It is necessary to distinguish between aggressive war against non-Muslims who reject Muslims' invitation for peace and Islam, and defensive war that aims preventing enemy invasion. Both wars are religious (and just), but the earlier war is Individual duty (farḍ al-'ayn) while the later is sufficiency duty (farḍ al-kifāya) (Sadralshariyah al-Sani, 172). Undoubtedly, one can easily justify the defensive war based on the new international law because the new international law system consider self-defense a basic duty of states, which seek their rights in survival and self-defense. However, some think that aggressive war for freedom of religion spread is incompatible with the principle of religious freedom, a principle accepted in Islam and the new law systems. Muslim jurists are opposed to the idea of aggressive war and believe that such war is optional if aims creating freedom to spread the religion. They emphasis that jihad is not legitimate per se, but what justify it is being in God's way namely in defense of liberty. (Taftazani, 191-2)

In fact, jihad has historical roots. Islam like any other religion began its work only based on invitation. In the beginning, Islam attempted only to addressing the human mind and justifying it, and many verses in Quran confirms clearly the matter that there is no compulsion and coercion in religion. Jihad did not exist in the tradition of the holy Prophet (PBUH\&HP) during the most times of his prophecy in Mecca. Then, when the prophet (PBUH\&HP) was prevented from staying in Mecca by the unbelievers after his peaceful invitation and moved out of the city, the first verse related to jihad was revealed against those who had deprived Muslims of freedom of invitation in Mecca. For this reason, Islam began a deep and gradual change towards a political and religious system, and became a government with army. Therefore, it was natural that the Islamic State can use his army for self-defense and to assist the oppressed callers to this right invitation.

The Prophet (pbuh\& HP) as head of this state believed that the establishment of this state requires the integration of the Arabian Peninsula (Hijaz) under a government that respects freedom of opinion and invitation, and that Islam makes Islam the single religion in the Arabian Peninsula. It must be emphasized that the Prophet (PBUH\&HP) also intended to spread the invitation beyond the Arabian Peninsula and in neighboring countries such as Syria and Iran. He (PBUH\&HP) did not let establishment of another religion besides Islam in the Arabian Peninsula, while makes other countries free in accepting Islam or paying tax (jizya) for supporting them and the guarantee of their religious freedom.

The companions after the death of the Prophet (PBUH\&HP) went beyond the borders of the Arabian Peninsula and towards the Islamic border. In order to justifying the legitimacy of the victories and next conquests they

\footnotetext{
${ }^{2}$ Ajvebatul Estiftaat of the Supreme Leader (Ayatullah Khamenei) P. 1048.
} 
referred to the texts and Quranic verses revealed against the infidels from the Arabian Peninsula, especially Quraysh who had prevented their freedom of invitation and opinion. For this reason, the question that those wars are legitimate war without a struggle has been a matter of emulation in Sunni jurisprudence.

Since the verses they were using to justify their wars, are in principle for to the status of the Arabian Peninsula, but the Sunni scholars used them for wars with other countries due to consensus that is of resources of Islamic jurisprudence. However, from the views of the jurists in respect of jihad can be concluded that: first, aggressive war may be legitimate only for one purpose, namely to protect freedom of invitation to Islam and for the way of Allah, but, if its goal is the domination and conquest over countries, it will be illegitimate. Second, jihad for the freedom of invitation is permissible and not obligatory, but is not permissible when Muslims are not able to do so. On the other hand, even if the two mentioned conditions are met, it is a sufficiency duty. In addition, the caliph has authority to declare war against unbelievers or limit the mutual relationship to conclusion of peace agreements. (Saduq, 204/5)

In a conclusion about the scope of the powers of the Islamic leader for declaring jihad from the perspective of Sunni thought system it can be said that the main theory is theory of existence of necessity for the interest of freedom of Islamic invitation. Early Muslims, depending on the civilization based condition of their era, recognized necessity of an aggressive war in order to guarantee the freedom of invitation and considered invasion as the best means for defense. This means that Sunni jurists consider the primary jihad necessary in case of clear existence of the interest of Islam and Muslims. ${ }^{3}$ In their view, complying with the leader in the matter of jihad is obligatory like obligatory prayers while most Shia jurisprudents believe that the primary Jihad and even its legitimacy is subject to the approval and permission of the Imam (AS) or his deputy. ${ }^{4}$

\section{Scope of the Guardianship of Government (Caliph)}

Islamic scholars believe that guardianship of government (caliphate) contains all the lands of Islam. By the lands of Islam, we mean all territories under government of Muslims. Accordingly, it is necessary to establish a single government (represented by a Caliph) for all the Islamic territories. Therefore, the basic principle in the Islamic public law is unity in the sense of government unity. For the earlier Sunni thinkers, unity means existence of a single Islamic power centre in the world that the Caliph represents it.

Unity is the most important feature of the right Caliphate in Islam or Rashidun Caliphate. Therefore, it is necessary to examine two issues: 1. the unity of the central power (the Caliphate), 2. The state of separation of some lands of central power (caliphate). However, over time the Sunni world was divided into separate countries and many Caliphs. Therefore, the Caliphate theory needs development. However the main view is that the community of Muslims cannot have various Caliphs. Given the current conditions, a question is that should the Caliph make his guardianship obligatory to all the Islamic countries? Whether he can let some of these countries to be independent of the caliphate until their power is limited to their certain territory, and until they do not conflict with the Caliph. Some believe that due to historical facts this is possible. However, it is necessary to note two points: 1) since inclusive caliphate sovereignty is necessary to ensure the unity of the Islamic world, this principle must be enforced with special care. The most important matter is maintenance of the Islamic unity, but the form of such unity is subject to conditions. 2) other than the territories of the land of Islam that are under the authority of the Caliph, some Islamic lands are located in the alien countries beyond the land of Islam such as Muslims living in China, Poland, or the Balkans, and it seems Caliph cannot extend his political sovereignty over these minorities. In addition,

Caliphate (Islamic state) must be independent of any foreign influence in the broad sense of the word, because it is not permissible that any non-divine sovereignty conquer the Islamic society. Therefore, the public guardianship of the Caliph must be single, universal and independent. Guardianship of the Caliph over Muslim citizens in the land of Islam is absolute. Then they are obliged to obey him according to the religious laws.

Of course, guardianship of the Caliph is not a personal right, but the Caliph's guardianship over Muslims does not include any spiritual power. However, he undertakes various religious duties and powers and his guardianship is not excluded to public law realm, but also includes some of private law matters such as marriage and testate.

Generally, Islamic law is enforceable on the worldly affairs of non-Muslim citizens living in the land of Islam except for the cases in which they are free to express their beliefs and religious affairs. Jurists distinguish between the two groups: one, group includes the dhimmis (non-Muslim citizens), and other group includes

\footnotetext{
${ }^{3}$ See: Hisas, vol. 3, P. 154; Shams alaeme Sarakhsi, 1971, vol. 1, PP.156- 157; Ibn Qudama, vol 10, P. 371; Shokani, vol. 7, PP. $242-243$.

${ }^{4}$ For example, see: Koleyni, vol. 5, P. 23; Tusi, 2009, vol. 2, P. 8; Shahid Sani, vol. 3, P. 9.
} 
refugees i.e. foreigners residing in the land of Islam. The Dhimmis are required to pay zakat called "Jizya", which replaces the zakat tax that Muslims are required to pay. By paying this tax, they acquire the right to security and support.

On the other hand, they have to respect the laws and general rules of the Islamic system, and to refrain from any interference in the religion of Islam and from helping the enemies of the Islam against Islamic army. (Mavardi, 127-130) Any disruption in doing these tasks will result in the loss of their rights. It is necessary that non-Muslims have permission to leave the land of Islam before being treated as enemies, but when they use arms against Muslims; actually, they will become enemy. (Ibid) Refugees are foreigners from the non-Islamic lands whose life and property are protected due to agreement. They can stay in the land of Islam without paying tax for four months, but for one year or more staying, they have to pay these taxes...(Ibid).

\section{Conclusion}

According to the intellectual and religious evidence, establishment of Islamic state namely a state based on God's laws is necessary. The head of such state must be scholar for understanding the divine laws and has capacities to solve the problems of society. From the Shia perspective, after the Prophet (PBUH\&HP) and the Imams (AS) in the occultation of Imam Mahdi (AS), this authority and responsibility is for the just jurist. Guardianship of the Islamic jurist is indeed public representativeness of infallible Imam (AS) and means administration of the Shiites' affairs during the occultation of Imam Mahdi (AS).

However, Sunni scholars consider Imamat a secondary and juridical issue.They believes that God does not need to order on leadership of Muslims after the Prophet (PBUH\&HP) and there is no divine command in this respect. (However, this belief is incompatible with various hadiths quoted by the famous Sunni scholars as well as Quran verses) They believe that government is transferred to the Caliph through various ways, sometimes with allegiance (such as the first Caliph) and sometimes with orders of the previous Caliph (like the second Caliph) and sometimes with the Council (e.g. the third caliph), and sometimes by force, and that in any case, Muslims must obey the governor, no matter evil or just.

One of the most important issues in the scope of guardianship of the jurist or Caliph is the guardian-less activities. Guardianship in these activities means priority of the jurist in doing them. There are two theories about the authority of the Islamic leader. One theory limits the scope of guardianship to the guardian-less activities while the other theory extends it beyond such activities because otherwise many of the Islamic society's affairs will be chaotic.

One of the most important issues in the realm and scope of the guardianship of Caliphate in Sunni Islam and jurist in Shiite Islam is jihad and there are many verses and hadiths about it. Jurists divide jihad into primary and defensive jihad. Primary Jihad is fighting the infidels and inviting them to Islam. Defensive jihad is fighting the invaders to life, property or the land of the Muslims.

There is no doubt that defensive jihad is not subject to the permission of the infallible Imam (AS); but, for Shia jurists the necessity of primary jihad is subject to the permission of the infallible Imam (AS), and is duty of the person who is appointed by Imam (AS). Thus, in the view of Shia Islam, primary jihad with the permission of qualified jurist during the occultation is not legitimate and he does not have such authority, while Sunni scholars only accept defensive jihad authority for their Caliph.

From the perspective of Sunni Islam, it is necessary to establish a single government (represented by a Caliph) for all the Islamic territories. Therefore, the basic principle in the Islamic public law is unity in the sense of government unity. For the earlier Sunni thinkers, unity means existence of a single Islamic power centre in the world that the Caliph represents it. Unity is the most important feature of the right Caliphate in Islam or Rashidin Caliphate. Guardianship of the Caliph over Muslim citizens in the land of Islam is absolute and thus they have to obey him according to the religious laws.

\section{References}

Akhund Khorasani, Mohammad Kazem ibn-Hussein, Kifaya al-Osoul, Tehran, Islamia, Bita.

Al-Bahr al-Ulum Hasani Hussaini Tabatabai, S.M. Ibn M.T Ibn Riza,Balaghahul Faqih, Najaf, Maktabah Al-Alamin al- Amah of Najaf,1984.

Amid Zanjani, Abbasali, Political Jurisprudence, Tehran, Majd Press, 2013.

Amoli, Mohammad Taghi, Almakasib va Bay, Qom, Islami Publications, Bita.

Ansari, M. Bin Mohammad Amin, Book of Khums, BIJA, BITA, the first edition, 1415 AD. 
Ansari, M. Bin Mohammad Amin, Makasib (new) 6 volume, the International Congress of Sheikh Ansari, 1415 AH, First Edition.

Asghar, Morvarid, Beirut, Daraltoras al-Islamiyah, first edition, 1410 AD.

Ayatollah Tabrizi, Sirat al-Nijah, Sediqah shahidah Press, Qom, 2009.

Azari Qomi, Ahmad, Vilayat e-Faqih from the Perspective of Islam, Qom, Daralilm Pub, 1994.

Bojnordi Mousavi, Seyed Mohammad, Civil Jurisprudence, Tehran, Majd Publications, First Edition, 2010.

Bojnurdi, Seyyed Hassan, Montaha al-Osoul, Tehran, Institute of Orouj, second edition, 2007.

Borji, Yaghuob Ali, Vilayat e Faqih in the view of Jurists,Tehran, SAMT Publications, 2007.

Fazel Lankarani, Mohammed, Alhodud (Tafsil al-Sharia fi Tahrir al-Vasilah), jurisprudence Center of pure Imams (AS), Qom, first edition, $1422 \mathrm{AD}$.

Hadavi Tehrani, Mahdi, Guardianship and Religiousness, Qom, House of Wisdom Cultural Institute, 2000.

Hakim, Seyed Mohsen, Mostamsek al-Urvatol Wusqa, Beirut Darahya’ Altoras al-Arabia, 1390 AH.

Halabi (Abul-Salah Halabi), Taqi ibn Najmaddin bin Ubaidullah, al-Kafi fi al-fiqh, Qom, Bustane Ketab Pub, second edition, $1430 \mathrm{AD}$.

Hashemi Golpayegani, Mohammad Reza, Alhidayah Ila Man lahu al-Vilayah, written by Saberi Hamadani, Qom, Ilmiyah press, 1383 AH 69.

Holy Quran.

Hurr Ameli, Mohammad ibn Hassan, Wasael al-Shia, Beirut, Darahya' Altoras al-Arabi, fourth edition, 1391 AD.

Ibn al-Shahid al-Sani, Hassan Bin Zainuddin, Maalim al-Osoul, Qom, Dar al-Fikr Institute, first edition, 1374 $\mathrm{AD}$.

Ibn Khaldun, Abu Zaid Abd al-Rahman ibn Muhammad, Introduction, Beirut, Manshurat Uwaydat, 1989.

Ibn Qulveyh, Jafar ibn Mohammed, Kamil al-Ziyarat, Qom, Fiqaha publishing, fifth edition, 1429 AD.

Iji, Azod aldin Abdul Rahman bin Ahmad, Almavaqif fi Ilm al-kalam, Qom, Sharif Razi, 1995.

Iravani, Ali, Margin on Almakasib, Tehran, rashidiyeh Press, 1379 AH.

Jafarian, Rasoul,Evolutionary History of State and Caliphate from the Rise of Islam to fall of Soffianian, Qom, Bustane Ketab Publications, Fifth Edition, 2009.

Javadi Amoli, Abdullah, Velayat-e Faqih, Guardianship of Jurisprudence and Justice, Qom, Asra Publishing Centre, fourth edition, 2005.

Kadivar, Mohsen, Vilayi Government, Tehran, Ney Publications, 2000.

Karami, Hamed, Mohebbi Davood, Theory of Government in the Sunni Jurisprudence, Tehran, Mizan Publications, first edition, 2014.

Khamenei, Seyed Ali. Ajvibah al-Istiftaat.

Khansari Najafi, Musa, Maniyah al-Taleb, Qom, Hekmat Pub, BITA.

Khoi, Abu al-Qasim, Minhaj al-Salihin, Volume 1, Edition 28, Madina al-ILM Publications, 1410 AH.

Khoi, Abu al-Qasim, al-Ijtihad va Taqlid, by S.M.M.M Khalkhali, Qom, Third Edition, New Publishing Centre,1411 AH.

Khomeini (Imam) Ruhallah, Kashf al-Asrar, Qom, Azadi press, first editions, bita.

Khomeini (Imam), Ruhallah, Sahifah of Imam, Tehran, Islamic Guidance Ministry, 1986.

Khomeini (Imam), Ruhallah, Tahrir ul-Vassileh, translated by Seyed Mohammad Bagher Mousavi, Qom, Daralilm Publications, Fifth Edition, 1998.

Khomeini (Imam), Ruhallah, the Book of Bay, Tehran, Institute for setting and Publication of the works of Imam Khomeini, second edition, 2006.

Khomeini (Imam), Ruhallah, the Islamic Government, Tehran, Institute for setting and Publishing the works of Imam Khomeini, second edition, $1391 \mathrm{AD}$.

Khomeini, Mustafa, Tahrirat fi-al-Fiqh (velayat-e faqih), Tehran, Institute for setting and Publication of the works of Imam Khomeini, in $1418 \mathrm{AH}$.

Koleyni, Mohammad ibn Yaqub, Usul al-Kafi, Tehran, Vali Asr Press, Second Edition, 1997. 
Lakzaie, Sharif, Comparative Study of Theories of Velayat-e faqih, Qom, Islamic Sciences and Culture Academy, 2007.

Makarem Shirazi, Naser, Bohus Feqhiya Hmah, School of Imam Ali bin Abi Talib, Qom, first edition, 1422 AD.

Margin on Makasib, Qom, Sama Qalam Pub, 2015.

Marifat, Mohammad Hadi, Conceptual Explanation of Absolute Vilayat e faqih, the Islamic State Journal, No. 15, 2001.

Mavardi, Ali ibn Mohammad, al- Ahkam Al-Sultaniyah fi al-Vilayat al- Diniyah, Beirut, Daralkitab al-Arabi, second edition, $1994 \mathrm{AD}$.

Mesbah Yazdi, Mohammad Taqi, A quick look at the Theory of Velayat-e faqih, Qom, Imam Khomeini Education and Research Institute Publishing, Seventh Edition, 2004.

Mirzaye Qomi, Abu al-Qasim ibn Muhammad Hassan, Qavanin al-Osoul, Tehran, Maktab al-Ilmiyah al-Islamiya, BITA.

Montazeri, Hossein Ali, legal foundations of Islamic Government, translated by Mahmoud Salavati, Tehran, Sarai Pub, Second Edition, 2001.

Naghibi, Abolqhasem, Comparative Study of the Rashidun Caliphate Theory of Sanhuri with the Absolute Guardianship of the Islamic Jurist theory of Imam Khomeini, Matin Research Journal, No. 55.

Naini, Mohammad hussain, Almkasb and Bai, written by Sheikh Muhammad Taqi Amoli, the Association of Teachers, Qom, first edition, 1413 AD.

Najafi, Mohammad Hassan, Jawahir al-Kalam, Beirut, Daralihya’ Altras al-Arabi, Seventh Edition, 1981.

Naraqi, Ahmd ibn mohammad mahdi Fazil, Avaid al-Ayam fi Bayani Qavaid al- Ahkam, Qom, Basirati Publications, $1408 \mathrm{AH}$.

Nasiri, Ali, Introduction to Islamic Sciences, Qom, Management Centre Press, Fifth Edition, 2005.

Ranjbarian, Mahdi, the Absolute Vilayat e-Faqih, Constitution and Imam Khomeini, Qom, Zafar Publications, 2003.

SAdralshariyah al-Sani, Ubayd Allah ibn Mas'ud, Mukhtasar al-Vaqayah, Tashkent, Mohammad Sharif Publishing, $1330 \mathrm{AH}$.

Saduq, Mohammed bin Ali bin Babawayh Qomi, 'Uyun al-Akhbar al-Riza, Tehran, Daralkitab al-Islamiyah, Fourth Edition, 2009.

Saduq, Mohammed bin Ali bin Babwayh Qomi, Kamal al-Din va Tamam al-Nimah, Qom, Institute of Islamic Publishing, Fifth Edition, 1429 AH.

Salehi Najaf-Abadi, Abdullah, Velayat-e Faqih; Rule of the Righteous, BIJA,Rasa Institute of Cultural Services, First Edition, 1983.

Sanaeefar, Mohammad, Story of Government, Tehran, Imam Sadiq (AS) University press, First Edition, 2015.

Soroush Mahallati, Muhammad, Religion and the Government in the Islamic Thought, Qom, Bustane Ketab Pub, 2008.

Tabarsi, Fazl ibn al-Hasan, Majma al-Bayan, Beirut, Dar al-Fikr, 1414 AH.

Tabrizi, Javad, Irshad al-Talib ilal Taliq ala al-Makasib, Qom, 1979.

Taftazani, Masoud ibn Omar ibn Abdullah al-shahir bisadiddin, Sharh al-Maqasid, Qom, al-Radi Press, 1409 $\mathrm{AH}$.

Vaezi, Ahmad, Theocracy; a Reflection on the Islamic Political Thought, Qom, Mersad Press, 2000.

Varaee, Seyed Javad, Consultation; the Right of People and the Duty of Government, the Islamic State Journal, No. 22.

\section{Copyrights}

Copyright for this article is retained by the author(s), with first publication rights granted to the journal.

This is an open-access article distributed under the terms and conditions of the Creative Commons Attribution license (http://creativecommons.org/licenses/by/3.0/). 